Journal of Social and Development Sciences

Vol. 3, No. 12, pp. 382-388, Dec 2012 (ISSN 2221-1152)

\title{
A Review of Post Privatization Performance of Ashaka Cement Manufacturing Company Nigeria PLC through the use of Financial Ratios
}

\author{
Abubakar Muhammed Magaji*, Sallahuddin Hassan \\ Universiti of Utara, Malaysia \\ *ammagaji2011@gmail.com
}

\begin{abstract}
Privatization as a reform policy package has been adopted by both developed and developing countries' economies. Nigeria as a developing country has large public enterprises which has about 57 percent of fixed capital investment and about 66 percent of formal sector employment by 1997. These enterprises performed below expectation due to multiple problems. Technical Committee on Privatization and Commercialization (TCPC) was set up to privatize the enterprises and the privatization have since commenced. The paper reviewed Ashaka cement company performance as a privatized enterprise after privatization. Managers of business organization must have reliable analytical tools for taking a rational decision. Ratio is one of such tools. Time series data from Ashaka Cement Company was used. The performance of the company has improved after privatization.
\end{abstract}

Key words: Public enterprise, ratios, performance, ashaka cement Nigeria

\section{Introduction}

Privatization of state-owned enterprises (SOEs) has become a key component in the reform package strategy for developing the economies. Several developing and transition economies have embarked on extensive privatization programs in the last two and a half decades as a means of attaining macroeconomic stability, fostering economic growth and managing public sector borrowing arising from corruption, subsidies and subventions to SOEs (White and Bhatia, 1998). In line with the trend worldwide, the spate of empirical works on privatization has also increased, albeit with a microeconomic orientation that emphasizes efficiency gains [Jerome (2008), La Porta and López-de-Silanes (1997); D’Souza and Megginson (1999); Boubakri and Cosset (1998); Dewenter and Malatesta (2001)]. Yet despite the increase in research, our understanding of the privatization program in Africa is inadequate. Apart from speculative postulations, not much is known about the procedures and result of privatization exercises in Africa in spite of the impressive level of activism in its implementation (Jerome, 2008). Current research is yet to provide useful insights into the peculiar circumstances of Africa, such as the presence of embryonic financial markets and weak regulatory institutions and the manner in which they influence the pace and outcome of privatization efforts. Most objective observers agree, however, that the high expectations of the 1980s about the "magical power" of privatization bailing Africa out of its quagmire remain unrealized [Adam et al. (1992); World Bank (1995); Ariyo and Jerome (1999); Jerome, (2005). Nigeria as a developing country witnessed the growing involvement of the state activities in the economy. The extension of government into different economic activities was viewed as an important strategy for fostering economic growth and development. This view was reinforced by substantial foreign exchange earnings from the crude oil sells in 1970s, which fuelled Federal Government of Nigeria investment in public enterprises (PEs) (Magaji, 2007). Nigeria's public enterprise sector is one of the largest in sub-Saharan Africa in terms of both scale and scope as reflected in the absolute numbers of enterprises and the contribution to the gross domestic product. Since the colonial era, public enterprises have assumed diverse and strategic development roles in the Nigerian economy. These covered large basic industries (manufacturing, agriculture, services, public utilities and infrastructure). They also includes: telecommunications, power, steel, petrochemicals, fertilizer, vehicle assembly, banks, insurance and hotels etc (Jerome, 2008). According to Zayyad (1990), prior to the privatization, there were about 600 PEs at the federal level and about 900 smaller PEs at the state and local levels. Shares of employment, value added and gross fixed capital formation of PEs generally exceeded those of other African countries. The estimated 1,500 enterprises accounted for about 57 percent of aggregate fixed capital investment and about 
66 percent of formal sector employment by 1997. It is estimated that successive Nigerian governments invested about 800 billion naira (approximately US $\$ 90$ billion equivalent) in the PE sector over two decades, which remains currently one of the largest in Africa (Jerome, 2008).

Nigerian Public Enterprises Performance: The magnitude, scope and persistence of failure of Nigeria's PEs have been extraordinary. These enterprises require continuous massive subsidies but deliver only intermittent and substandard services; industrial enterprises typically operate at $10-35$ percent of capacity. The returns on these large investments have generally been poor, and in a number of cases negative, with an especially low rate of return relative to the large amount of resources invested in them. It has been estimated that total investment in the public enterprise sector exceeded US $\$ 35$ billion, comprising US $\$ 12.5$ billion in equity, US $\$ 10.2$ billion in government loans, and another US $\$ 11.5$ billion in unspecified and largely unrecorded subventions to various enterprises. These investments provided meager returns, yielding US $\$ 1.5$ billion in dividends and loan repayments from 1980 to 1987 (Federal Government of Nigeria, 1986). Furthermore, about 40 percent of non-salary recurrent expenditure and 30 percent of capital expenditure was expended annually on the state-owned enterprises. The reasons for the poor performance of PEs in Nigeria are documented. These include among others, the lack of residual claimant to profits, the presence of multiple and conflicting objectives determined by politicians and the prevalence of incomplete contracts and government subsidies that protect internal inefficiencies and perpetrate soft budget constraints (Jerome, 2004). In the Nigerian, political expediency rather than economic viability govern key project parameters such as plant location, capacity planning, implementation timeframe, employment and product/service pricing. Some of the large-scale projects especially in agriculture and industrial sectors have been on the drawing board for periods ranging from 10 to 35 years. A case in point is the Ajaokuta steel plant, which remained uncompleted for as long as 30 years. Inefficiencies were also perpetrated due to misuse of monopoly powers, notably in infrastructure, resulting in unreliable delivery and availability of services, including for the poor. Other contributions to this dismal picture have been excessive bureaucratic controls and government intervention; inadequate policy and regulatory frameworks that impede competition, discourage private entry and private investment; weak capacity to implement reform; and gross mismanagement and nepotism. These were compounded by a control and management structure that was extremely complex, opaque and prone to political capture (Ierome, 2008). The result was that Nigeria underachieved its growth potential as a result of a huge PE sector weighed down by inefficiency and massive corruption. For example, the unreliable power supply from the National Electric Power Authority (NEPA) is estimated to impose an additional cost of around US\$1 billion annually on the economy

PE deficits have been a major source of fiscal problems and a drag on growth (World Bank, 1995). In the wake of the economic recession that began in 1981 following the collapse of oil prices, the activities of PEs attracted more attention and underwent closer scrutiny, much of it centering on their poor performance and the burden they impose on fiscal policy. With the unfortunate returns of finances from these enterprises, and against the background of severe macroeconomic imbalance and public sector crisis, precipitated the concern of government towards privatization In fact, by 1984 the World Bank and International Monetary Fund (IMF) were increasingly advocating for privatization as a policy tool in Nigeria. The privatization program was subsequently adopted as part of the structural adjustment program embarked on in July 1986. In July 1988 a Decree No.25 on privatization and commercialization was promulgated. The decree gave legal backing to and formally initiated Nigeria's privatization and commercialization program, thus marking the first comprehensive approach to divestiture embodying an institutional focus and a clearer program. The decree listed 145 enterprises to be affected by the exercise. A total of 111 enterprises were slated for full and partial privatization, while 35 others were to be commercialized. The list was later amended in order to convert five enterprises from partial privatization to full commercialization; those five were Nigerian Industrial Development Bank Limited; Nigerian Bank for Commerce and Industry Limited; Federal Mortgage Bank Limited; Federal Super Phosphate Fertilizer Company Limited; and National Fertilizer Company of Nigeria. According to the decree, the program is expected to restructure and rationalize the public sector in order to lessen the preponderance of unproductive investments; reorient the enterprises towards a new horizon of performance improvement, viadilitant overall efficiency; ensure positive returns on investments in commercialized public enterprises; check absolute dependence of commercially-oriented parastatals on the treasury and encourage their patronage of the capital market; and initiate the process of gradual cessation of 
public enterprises that can be best managed by the private sector. In conformity with the provisions of the decree, an 11-person Technical Committee on Privatization and Commercialization (TCPC) was inaugurated on 27 August 1988 with a broad mandate to coordinate the rehabilitation of government enterprises and oversee Nigeria's privatization program. The actual divestiture commenced in the early months of 1989 with the shares of four firms (Flour Mills of Nigeria, African Petroleum, National Oil and Chemical Company, and United Nigeria Insurance Company) being issued in the market. The shares were successfully sold with each issue reportedly oversubscribed. From 1988 to 1993 when the privatization process was suspended, 55 firms had been privatized by the TCPC of which Ashaka Cement Company was among (TCPC, 1993).

Ashaka Cement Company PLC: The Company is located and commenced operation in Gombe State in July 1974. It was integrated as Private Liability Company in 1981 and was converted into a public company in 1985, prior to privatization exercise, the company's shares were held as follow: Federal Government of Nigeria (48 percent); Bauchi State Government (10 percent); Gombe State Government (10 percent); Adamawa State Government (10 percent); Taraba State Government (10 percent) and Blue Circle Industries Plc, UK (Foreign Technical Partner) (12 percent). The main activity of the company is the manufacturing and marketing of cement product.

\section{Conceptualization of Ratios}

To make rational decisions in keeping with the objectives of the firm the manager especially financial manager must have analytical tools. The more useful tools of financial analysis are the ratios analysis. The company is in a fish bowl subject to credit and investor analysis. The purpose is not only internal control but also better understanding of what the various individual players seek in financial condition and performance from it. A ratio is defined as "the indicated quotient of two mathematical expressions" and as "the relationship between two or more things (Pandey, 1995). In financial analysis, a ratio is used as a benchmark for evaluating the financial performance of a firm and its position. A figure in accounting conveys meaning when it is related to some other relevance information. For example $\$ 5$ million net profit may be perceive as remarkable, but performance of the firm can be said to be good or bad when the net profit figure is related to the investment of the firm. The two accounting figures relationship expressed mathematically is known as a financial ratio or simply as a ratio (Pandey, 1995). Ratios help to summarize the large quantities of financial data and to make qualitative judgments about the firm's financial performance. Bernstein (1974) believes that a ratio is an expression of mathematical relationship between one quantity and another usually expressed as a fraction, a percentage, a decimal or integer. Simon (1988) argues that ratios can be presented in a number of forms such as percentage where one figure is divided by another and multiplied by 100 , as a fraction where one figure is divided by another. A period of time where one figure is divided by another and multiplied by a time period and finally, as a proportion by setting one figure to 1 showing the other figure as its relative value to 1 . To be useful, ratios must be compared with earlier periods to indicate trends or compared with similar organizations in the same industry to determine strengths and weakness, or ideally compared with the industrial average, if such can be obtained, to show position in the industry (Okwoli, 2009).

Types of Ratios: The calculated ratios can be grouped into various classes according to financial activity or function to be evaluated.

Liquidity Ratios: It is extremely essential for a firm to meet its obligations. The ability of the firm to meet its current obligations is measured by liquidity ratios. A company must ensure that it does not experience lack of liquidity often, and also does not have excess liquidity i.e. it should maintained balance. If the company failed to meet its obligations as a result of sufficient liquidity, this situation may leads to reduced creditworthiness, loss of creditor's confidence, or even closure of company. A very high degree of liquidity is also bad; idle assets make no earning. The company`s capital will be unnecessarily tied up in current assets. Strike a proper balance between high liquidity and lack of liquidity is therefore, necessary. (Pandey, 1995).

Leverage Ratios: As explained earlier on, creditors in short-term, like suppliers of raw materials and bankers are more alarmed with company`s debt-paying ability. Likewise financial institutions, debenture holders etc 
who are long-term creditors, are apprehensive with the firm's enduring financial strength. It is opined that a firm should have a tough long-term as well short-term financial position. To critic the financial position of the firm, capital structure, or financial leverage, ratios are calculated (Pandey, 1995) these ratios indicate mix of funds provided by owners and lenders. The manner in which assets are financed has a number of implications. First, between equity and debt, more risky from the firm's point of view is debt. The company has a legal obligation to pay interest to debt holders, irrespective of the profits made on losses incurred by the firm. If the company fails to pay to debt holders in time, they can take action against it to get payments and in acute cases, can force the company into liquidation. Second, debt employment is beneficial for shareholders in two ways: (a) they can retain control of the firm with a limited stake and (b) their earning will be overstated. (Pandey, 1995). Thus, use of debt magnifies the shareholders' earnings as well as increases their risk. Third, a highly debt-burdened company will find difficulty in raising funds in future. The owners' equity is treated as a margin of safety by creditors; if the equity base is thin, the creditors risk will be high. Thus, ratios are calculated to measure the financial risk and the firm's ability of using debt to shareholder's advantage.

Total Debt Ratio: Several debt ratios may be used to analyze the long-term solvency of a firm. The firm may be interested in knowing the proportion of the interest-bearing debt in the capital structure. It may, therefore compute debt ratio by dividing total debt (TD) by capital employed (CE) or total net assets (NA). Total net debt will include short-term and long-term borrowings from financial institutions, and bank borrowings.

The Activity Ratios: Funds of creditors and owners are invested in various assets to generate sales and profits. The better managed the assets, the larger the total of sales. The efficiency is evaluated by employing activity ratios with which the firm manages and utilizes its assets. These ratios are also known turnover ratios, since they indicate the speed with which assets are being converted or turned over into sales. The activity ratios, involve a relationship between sales and assets. A balance among sales and assets generally reflects that assets are managed well. Many activity ratios can be calculated to judge the effectiveness of asset utilization (Higgins, 2004). Inventory turnover ratio indicates the efficiency of the firm in its products selling.

Profitability Ratios: A company should earn profits to survive and grow over a long period of time profit is the difference between revenues and expenses over a period of time. The ultimate output of a company is profit, and it may not have future if it fails to make sufficient profits. Consequently, the manager should continuously evaluate the efficiency of its company in term of profits. The ratios are intended to measure the operating efficiency of the company. Management of the company, creditors and owners of the firm are interested in its profitability. Creditors want to get repayment and interest of principal regularly. Owners want to get return on their investment. This is possible only when the company earns enough profits.

The Importance of Ratio Analysis: The ratio analysis is the most powerful tool; many groups of people are involved in analyzing the financial information of a firm to indicate the operating, financial efficiency, and growth. People use ratios to determine those financial characteristics of the firm in which they are interested. With the ratios, one can determine the ability of the firm to meet its current obligations; the extent to which the firm has used its obligation solvency; the efficiency with which the firm is utilizing its assets in generating sales revenue and the overall operating efficiency and performance of the firm (Pandey, 1995). The shortterm creditor will be interested in current financial situation of the firm, as long-term creditor will pay more attention to firm solvency. The shareholders are generally alarmed with return and may bother about the firms' financial condition only when their earnings are depressed; in fact, it has to be realized that the short and long-term financial position and the profitability of the firm are tested in every kind of analysis than others. If a short-term creditor analyses only the current position and finds it satisfactory, he cannot be certain about the safety of his claim if the firm's long-term financial position or profitability is unfavorable. In credit analysis, the analysis will usually select a few important ratios. He may use the current ratio or quickasset ratio to judge the firm's liquidity or debt-paying ability; debt equity ratio to determine the stake of the owners in the business and the firm's capacity to survive in the long-run. The ratio is also useful in firms' financial safety analysis. The major focus in safety analysis is on the long-term profitability. Profitability is dependent on a number of factors and, therefore, the safety analyst should also analyse other ratios. He would certainly be concerned with the efficiency with which the firm utilizes its assets and the financial risk to which firms is exposed. Therefore, besides analyzing the profitability ratios meticulously, he will also 
analyze activity ratios and leverage ratios. The detailed analysis of the earning power is important for financial safety analysis.

The ratios of a firm by themselves do not reveal anything. For meaningful interpretation, the ratios of a firm should be compared with the ratios of similar firms and industry. This comparison will reveal whether the firm is significantly out of line with its competitors. If it is significantly out of line, the firm should undertake a detailed analysis to spot out the trouble areas. The ratio analysis will reveal the financial condition of the firm more reliably when trends in ratios over time are analyzed. Ratios at a point of time can mislead the analyst, because they may be high or low for some exceptional circumstances at the point of time. An impressive present financial position may really be eroding over time, while a weak position may be improving at a rapid rate over time. Thus, the trend analysis of the ratios adds considerable significance to the financial analysis because it studies ratios of several years and isolates the exceptional instances occurring in one or two periods. Although the trend analysis of the company's ratios itself is information, but it is more informative to compare the trends in the company's ratios with the trends in industry ratios. This comparison indicates how well the company has been operating over time relative to its competitors and may also help to explain the trends in the company's ratios.

\section{Methodology}

The paper used secondary data. The efficiency is measured as percentage change in performance of the firms and the T-test percentage change in performance of each of the proxy, in both the periods of pre and after privatization. The study examines the same variables that are used by Boubakari and Cosset (1998), (Megginson, et al., 1994), and D Souza and Magginson (1999). The study makes use of proxies per variable. Profitability variables are measured in percent and local currency is used for analysis. The data collected was processed into ratios as the devise for measuring the performance of the enterprise before and after privatization. All ratios before privatization were represented by $X_{1}$ while all ratios after privatization were represented by $X_{2}$. The means (averages) of pre and post privatization ratios were calculated and

represented by $\bar{X}_{1}$ and $\bar{X}_{2}$ respectively. A higher mean ratio in succeeding era suggests that there is an improvement in the performance of the enterprises. The difference of two then used to establish whether or not there has been significance deference in terms of profitability and efficiency before and after privatization. Since the population variances are not know and the sample size is small (i.e. less than 30), the $t^{*}$ test was applied.

The $t^{*}$ equation is given as follows:

$t^{*}=\frac{\bar{X}_{1}-\bar{X}_{2}}{S_{m}}$

and

$S_{m}=\frac{S_{1}^{2}}{n_{1}}+\frac{S_{2}^{2}}{n_{2}} ; S_{1}^{2}=\sum\left(X_{1}-\bar{X}_{1}\right)^{2}$ and $S_{2}^{2}=\sum\left(X_{2}-\bar{X}_{2}\right)^{2}$

where:

$\bar{X}_{1}$ is the mean of performance ratios before privatization

$\bar{X}_{2}$ is the mean of performance ratios after privatization

$S_{m}$ is the standard deviation where

$S_{1}^{2}$ is the variance for $X_{1}$

$S_{2}^{2}$ is the variance of $X_{2}$

$n_{1}$ is the sample size of $X_{1}$

$n_{2}$ is the sample size of $X_{2}$ 
The period of analysis covered some years before and some years after privatization. The average performance was calculated using efficiency and profitability ratios, which are shown below.

$\begin{array}{ll}\begin{array}{l}\text { Efficiency Ratios: } \\ \text { Total Asset Turnover (TAT) }\end{array} & \frac{S A}{T A} \\ \text { Fixed Asset Turnover (FAT) } & \frac{S A}{F A} \\ \text { Current Ratio (CR) } & =\frac{C A}{C L} \\ \text { Profitability Ratios: } & =\frac{N P}{S A} \\ \text { Net Profit Margin Ratio (NPM) } & =\frac{G P}{S A} \\ \text { Gross Profit Margin Ratio (GPM) } & \end{array}$

The following variables were used in calculating the ratios:

$\begin{array}{lll}T A & = & \text { Total Assets } \\ F A & = & \text { Fixed Assets } \\ S A & = & \text { Sales/Gross Earning } \\ N P & = & \text { Net Profit/Profit after Taxation } \\ G P & = & \text { Gross Profit/Profit before Taxation } \\ C A & = & \text { Current Assets } \\ C L & = & \text { Current Liabilities }\end{array}$

Table 1: Performance Rations of Ashaka Cement Company Plc.

\begin{tabular}{|c|c|c|c|c|c|c|c|c|c|c|c|c|}
\hline \multirow{3}{*}{ Ratios } & \multicolumn{6}{|c|}{ Before Privatization } & \multicolumn{6}{|c|}{ After Privatization } \\
\hline & \multicolumn{5}{|c|}{ Year } & \multicolumn{7}{|c|}{ Year } \\
\hline & 1994 & 1995 & 1996 & 1997 & 1998 & Average & 1999 & 2000 & 2001 & 2002 & 2003 & Average \\
\hline FAT & 0.01 & 0.001 & 0.2 & 1.5 & 1.50 & 0.64 & 2.33 & 2.08 & 3.90 & 3.90 & 4.81 & 3.40 \\
\hline TAT & 0.10 & 0.050 & 1.0 & 1.0 & 1.00 & 0.13 & 1.01 & 1.02 & 3.86 & 4.72 & 4.76 & 3.08 \\
\hline GPM & 0.50 & 1.200 & 0.2 & 1.2 & 0.22 & 0.66 & 2.29 & 3.80 & 3.03 & 4.39 & 5.08 & 3.72 \\
\hline NPM & 0.40 & 0.600 & 1.2 & 1.2 & 0.40 & 0.76 & 2.40 & 2.10 & 3.17 & 4.44 & 4.20 & 3.26 \\
\hline ROA & 0.20 & 0.500 & 1.0 & 0.8 & 0.50 & 0.60 & 3.00 & 6.20 & 5.2 & 8.40 & 10.0 & 6.56 \\
\hline ROCE & 0.20 & 0.500 & 1.0 & 0.8 & 0.50 & 0.60 & 3.00 & 6.20 & 5.2 & 8.40 & 10.0 & 6.56 \\
\hline ROSE & 0.20 & 0.800 & 2.8 & 3.2 & 3.20 & 2.24 & 6.00 & 6.50 & 8.2 & 8.50 & 27.0 & 11.24 \\
\hline
\end{tabular}

Note: Figures are expressed in percentage

\section{Results}

Table 1 represents the performance ratio of Ashaka Cement Plc. The two period pre-privatization and postprivatization of five years each. From the performance, the average FAT before privatization measured 0.65 percent while after privatization it increased to 3.40 percent with a growth rate of 2.76 percent for the periods covered. TAT increased from the average of 0.13 percent to 3.08 percent. Post Privatization with an increment rate of 2.95 percent depicting a remarkable improvement on revenue generation after privatization. GPM showed an increment in profitability growth rate from an average of 0.66 percent before privatization to 3.72 percent after privatization. A growth rate of 3.06 percent within the five year period measured. While the NPM rose from an average of 0.76 percent before privatization to 3.26 percent after privatization, with 2.5 percent net profit incremental growth rate. ROA and ROCE equalized by moving from 0.6 percent before privatization to 6.56 percent after privatization thus made an increased returned rate of 5.96 percent to assets and capital employed. The shareholders' equity went up by 9 percent from 2.24 percent before privatization to 11.24 percent after privatization 


\section{Conclusion}

Privatization as a component of state owned enterprises reform has been adopted by both developed and developing economies. It has been adopted for macroeconomic stability and growth. Nigeria has large public enterprises sector which covered the entire economy. The growth of public enterprises was due to the fact that the government had wished to have commanding height of the economy and the increase oil revenue of 1970s and early 80s. The country invested over 35 billion us dollar in the sector between 1980 to 1987 alone. These enterprises have performed poorly and reasons for its poor performance include multiple and conflicting objectives, inefficiencies and misuse of monopoly power etc. which resulted in the country underachieved economic development and growth. These problems lead the country adopt privatization as reform package. Now over 55 firms were privatized of which Ashaka cement was among. Various ratios are discussed and are used to measure the performance of the company before and after privatization. The result of this study indicated an improvement in the general performance of the company after privatization

\section{Reference}

Adam, C., Cavendish, W. \& Mistry, P. (1992). Adjusting privatization. Case studies from developing countries. James Curry: London.

Ariyo, A. \& Jerome, A. (1999). Privatization in Africa: An appraisal. World Development, 27(1), 201-13.

Bernstein, L. A. (1974). Understanding corporate report: A guide to financial statement analysis, New-York.

Boubakri, N. \& Cosset, J. (1998). The financial and operating performance of newly privatized firms: Evidence from developing countries. The Journal of Finance, LIII(3), 1081-110.

D'Souza, J. \& Megginson, W. L. (1999). The financial and operating performance of newly privatized firms during the 1990s. Journal of Finance, 54, 1397-438.

Dewenter, K. \& Malatesta, P. H. (2001). State-owned and privately-owned firms: An empirical analysis of profitability, leverage, and labor intensity. American Economic Review, 91(1), 320 - 35.

Federal Government of Nigeria. (1986). Structural Adjustment Program July 1986 - June 1988. Federal Government Information Memorandum, November.

Higgins, R. C. (2004). Analysis for financial management. The McGraw-Hill Companies Inc.: New York.

Jerome, A. (2004). Technical efficiency in some privatized enterprises in Nigeria. African Journal of Economic Policy, 11(1), 17-34.

Jerome, A. (2005). Privatization and regulation in South Africa: An evaluation. Chapter 6 in Edmund Amann, ed., Regulating Development Evidence from Africa and Latin America. Northampton, Massachusetts, and Cheltenham, UK: Edward Elgar Publishing Ltd.

Jerome, A. (2008). Privatization and enterprise performance in Nigeria: Case study of some privatized enterprises: African economic research consortium (AERC).

La Porta, R. \& López-de-Silanes, F. (1997). Benefits of privatization: Evidence from Mexico NBER Working Paper No 6215. National Bureau of Economic Research, Cambridge, Massachusetts.

Magaji, A. M. (2007). Privatization as an alternative development strategy for Nigeria (1986 - 2003). Unpublished M.Sc. Thesis, A.B.U. Zaria.

Megginson, W. L., Nash, R. \& Van Randenborgh, M. (1994). The Financial and Operating Performance of Newly Privatized Firms: An International Empiric Analysis. Journal of Finance, 49, 403-52.

Okwoli, A. A. (2009). The use of ratios in financial statement analysis and prediction of financial crisis in financial management and control, Edited, (ANAN, 2009).

Pandey, I. M. (1995). Essentials of finance management, Vikas Publishing House PVT Ltd.: New-Delhi.

Simon, J. (1988). Interpretation of financial statements: The use of ratios, ACCA students' Newsletters, October.

Technical Committee on Privatization and Commercialization (TCPC). (1993). Final report, one \& two. The Presidency, Abuja.

World Bank. (1995). Bureaucrats in business: The economics and politics of government ownership. New York: Oxford University Press.orld.

White, O. C. \& Bhatia, A. (1998). Privatization in Africa. The World Bank : Washington, D.C.

Zayyad, H. R. (1990). Privatization and commercialization in Nigeria: TCPC report, 1998. 